\section{The determinant of behavioral factors which influence on credit card usages}

\author{
M. Zubair Hussain ${ }^{1}$, Khushnood Habib ${ }^{2}$
}

The Journal of Educational Paradigms

2020, Vol. 02(02) 143-145

(C) Authors

ISSN (Print): 2709-202X

ISSN (Online): 2709-2038

DOI: $10.47609 / 0202052020$

\begin{abstract}
The purpose of this paper is to examine which behavior factor effect on credit card use. Among different behavior factors, which factor more positively and significantly influence credit card use? The data are collected from individuals who have a credit card through the Lahore questionnaire. The finding shows a strong influence of behavior factor on credit card uses especially perceived usefulness. And perceived risk has a positive impact on credit card use. The study is limited to only the service sector as a credit card. Convinces sampling technique is used. For further research, influence on customer or client income also takes into consideration. This research is no precious in Pakistan's credit card, which studies behavior influences credit card use.
\end{abstract}

Keywords: behavior factors (perceived risk, subjective norm, perceived usefulness, and perceived behavior control) and credit card use.

Credit card is a term that is defined as a useful financial tool, It permits the purchasers to acquire the monetary resources to meet the current requirements that are payable in exact future time (Syed Faheem Hasan Bukhari, 2015). Banks began to issue Master cards (credit card), the first time in 1946 after launching by National Bank (Brooklyn). After an extended period, it introduces in Pakistan by HBL, it was launched, yet it picked up acknowledgment after the 1990s with the dispatch of Citibank Pakistan Card. Still, now most of BOP provides the facility of Master cards like MCB, UBL, HBL, Allied, and Faisal bank. The bank issues Mastercard against charges premium and operating expense from the individual to whom Mastercard is issued (Shafinar Ismail, 2014).

Shafinar Ismail examines which attitudes are determinant of credit card usage. By taking variable knowledge, perception, family influence, media awareness, and religious belief, all variables have a substantial impact on credit card use expect religious belief (Syed Faheem Hasan Bukhari, 2015). Adam M. Hancock examines college and credit cards and found that Analysts, instructors, and policymakers would all help lessen the aggravating variables that affect why understudies have more Mastercard obligations (Jorgensen, 2013).

Financial instruments like credit cards are valuable for consumers to get financial resources for current utilization exchangeable in the upcoming date. In this study, we take the determinant of behavior factor that has their impact on credit card usage, so for that purpose here we take variable for behavior factors are the subjective norm, perceived risk, perceived usefulness. Perceived behavioral control as independent variable and credit card use as dependent variable.

Literature Review

In this study, the Indicator of behavior factor, we take four variable SN, PU, perceived behavior control, and perceived risk as independent variable and dependent variable take as credit card usage.
Subjective norm or social norm is a term that originates in the midfifties of the twentieth. Social standards depict an adjustment in thinking or sensation, concerned with explicit conduct because of contact with another person. In 1962, the comprehension with the deference of social standards was increasingly stretched out through work by (Eckhardt, 2009). The social norm was evident as the burden of individual or gathering to perform specific conduct on a person - questionnaire adopted from (Ajzen, 1991).

Perceived usefulness, defined as "how much an individual accepts that utilizing a specific system would improve his or her activity execution (Davis, 1989). (Sriyalatha, 2016) studied the determinants of Customers' Attitude towards Credit Card Usage: Lessons Learned from Academics in Sri Lanka and examine the impact of the use of card intention, Perceived usefulness, and available information on credit card usage. And there is an impotent or significant influence of PU on credit card usage. The questionnaire was adapted from (Davis, 1989).

According to the planned behavior theory (1991), the self-evident significance is PBC (perceived behavioral control). There is a direct connection between PBC, and behavioral accomplishment is that apparent social control can frequently be utilized as a substitute for a proportion of actual control. A higher degree of PBC ought to increase a person's aim to make the behavior, and the lower degree of PBC should be less inspired to perform the conduct (Barua, 2013). A questionnaire was adopted from (Ajzen, 1991).

Hardeep Chahal examines perceived risk as moderating variable and their impact on credit card use. They found that perceived risk has a strong moderately effect on Master card use, and risk also affects it. (Hardeep Chahal, 2014). Goyal examined the impact of perceived risk on credit card buying (Goyal, 2008). The questionnaire was adapted from (Bauer, 1960).

A Mastercard is an adaptable and advantageous approach to get cash and pay it back after some time. Suhana Mohamed researched which factor effect on the credit card use and found that It is discovered that solitary credit connected knowledge has a positive

${ }^{12}$ UCP Business School, Faculty of Management Studies, UCP, Pakistan. Zubairhussain1414@gmail.com 
impact on the credit card obligations. All in all, the Malaysian government ought to fix the rule of endorsing credit cards by a business bank (Suhana Mohamed, 2016). Credit cards' common utilization replicates buyer preference with respect to preset credit extensions, and technological advancements made it simpler for banks to offer rotating credit. Mastercard use is the measure of 'charges' made by a cardholder, either through buys of products and enterprises or loans made through ATMs given by Mastercards issuer (Syed Sharaf, 1998). The questionnaire was adopted from NFCS 2015.

H1: There is a positive association between $\mathrm{SN}$ and credit card use H2: There is a positive association between PU and credit card use H3: perceived behavior control has a positive and significant effect on CCU.

H4: perceived behavior control has a negative and significant effect on CCU.

H5: Perceive risk positively and significantly affects the Credit card user.

H6: Perceive risk negatively and significantly affects the Credit card user.

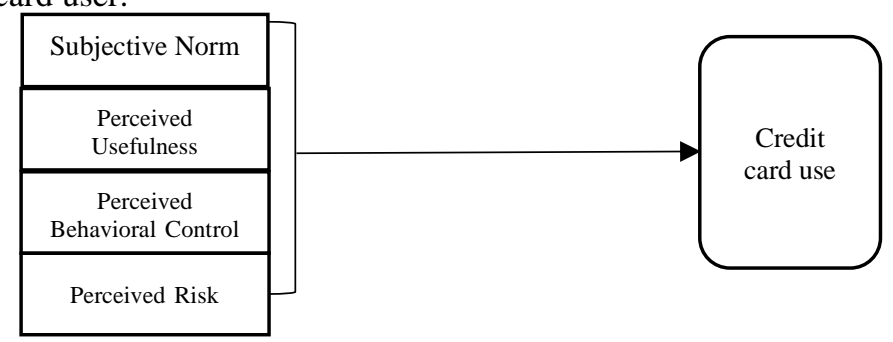

Figure 1: Conceptual framework

\section{Research Methodology}

Data collected from the credit cardholder. Random sampling technique is used. Data collected from 50 respondents (holder of the credit card). And the random sampling technique is used. Data gathered through the questionnaire by Primary study.

Table 1: Reliability Statistics

\begin{tabular}{|c|c|c|c|c|c|c|}
\hline \multicolumn{4}{|c|}{ Cronbach's Alpha } & \multicolumn{3}{|c|}{ N of Items } \\
\hline \multicolumn{4}{|c|}{.818} & \multicolumn{3}{|c|}{31} \\
\hline \multicolumn{7}{|c|}{ Table 2: Model Summary } \\
\hline Model & $\mathbf{R}$ & R Square & \multicolumn{2}{|r|}{$\begin{array}{l}\text { Adjusted R } \\
\text { Square }\end{array}$} & \multicolumn{2}{|c|}{$\begin{array}{c}\text { Std. The error of } \\
\text { the Estimate }\end{array}$} \\
\hline 1 & $.527^{\mathrm{a}}$ & .278 & & .214 & & 194 \\
\hline \multicolumn{7}{|c|}{$\begin{array}{l}\text { a. Predictors: (Constant), PR, SN, PBC, PU } \\
\text { Table 3: ANOVA }\end{array}$} \\
\hline Model & & $\begin{array}{l}\text { Sum of } \\
\text { Squares }\end{array}$ & Df & $\begin{array}{c}\text { Mean } \\
\text { Square }\end{array}$ & $\mathbf{F}$ & Sig. \\
\hline 1 & $\begin{array}{l}\text { Regression } \\
\text { Residual } \\
\text { Total }\end{array}$ & $\begin{array}{l}1.379 \\
3.577 \\
4.956 \\
\end{array}$ & $\begin{array}{c}4 \\
45 \\
49 \\
\end{array}$ & $\begin{array}{l}.345 \\
.079\end{array}$ & 4.337 & $.005^{\mathrm{b}}$ \\
\hline
\end{tabular}

a. Dependent Variable: ccu

b. Predictors: (Constant), PR, SN, PBC, PU

Table 4: Coefficients

\begin{tabular}{|c|c|c|c|c|c|c|}
\hline \multirow{2}{*}{\multicolumn{2}{|c|}{ Model }} & \multicolumn{2}{|c|}{$\begin{array}{c}\text { Unstandardized } \\
\text { Coefficients }\end{array}$} & \multirow{2}{*}{$\begin{array}{c}\begin{array}{c}\text { Standardized } \\
\text { Coefficients }\end{array} \\
\text { Beta } \\
\end{array}$} & \multirow[t]{2}{*}{$\mathbf{T}$} & \multirow[t]{2}{*}{ Sig. } \\
\hline & & B & Std. Error & & & \\
\hline \multirow{5}{*}{1} & (Constant) & 1.403 & .277 & & 5.06 & .000 \\
\hline & SN & .023 & .043 & .068 & .52 & .599 \\
\hline & PU & .191 & .070 & .429 & 2.74 & .009 \\
\hline & PBC & .040 & .075 & .083 & .53 & .595 \\
\hline & PR & -.241 & .072 & -.465 & -3.33 & .002 \\
\hline
\end{tabular}

a. Dependent Variable: ccu
The result shows that the p-value of the subject norm and PBC is not significant, so there is an insignificant relation with CCU because the p-value is greater than .05 . The perceived usefulness relationship is substantial with CCU because of the p-value of less than .05(.009). The perceived risk relationship also has a significant relation with CCU because the p-value is less than .05 (.002). The result showed that PU and PR have a positive and significant impact on CCU. From ANOVA, it shows that overall independent variable. A substantial predictor of CCU. The R square is .527 , indicating that the independent variable explains almost $53 \%$ variation in CCU.

Descriptive statistics the analysis of measure (mean, maximum, minimum, and standard deviation regarding independent and dependent. Variable and other age, gender, level of education, and monthly spending of CC show data normality.

Table 5: Descriptive statistics

\begin{tabular}{lcccc}
\hline & Minimum & Maximum & Mean & Std. Deviation \\
\hline Age & 1 & 4 & 1.90 & .931 \\
Gender & 1 & 2 & 1.42 & .499 \\
education level & 2 & 4 & 3.42 & .609 \\
Spending & 1 & 4 & 2.62 & .945 \\
SN & 1.00 & 4.80 & 2.5200 & .95874 \\
PU & 1.71 & 4.57 & 3.6229 & .71210 \\
PBC & 2.14 & 4.86 & 3.7200 & .65812 \\
PR & 1.67 & 4.50 & 3.0113 & .61377 \\
Ccu & 1.00 & 2.00 & 1.5767 & .31803 \\
\hline
\end{tabular}

\section{Correlations}

The correlation analysis technique is used to find out the association among two variables. Correlation is significant at the 0.01 level (2-tailed).

Table 6: Correlation Analysis

\begin{tabular}{lccccc}
\hline & SN & PU & PBC & PR & CCU \\
\hline SN & 1 & & & & \\
PU & .023 & 1 & & & \\
PBC & .005 & .000 & 1 & & \\
PR & .047 & .007 & .011 & 1 & \\
CCU & 0.00 & .027 & .259 & .061 & 1 \\
\hline
\end{tabular}

The results show that the co-relational is significant between dependent variable and three independent variables by the substantial standard at the 0.01 level (2-tailed). CCU has a positive relationship with the subjective norm because it is less than 0.05 . The perceived risk's correlation value is 0.061 , which shows a significant and positive connection with credit card use at 0.05 significant levels. Perceive usefulness is also correlated significantly with CCU at value 0.027 . But PBC has a correlation value of 0.259 , which greater than the significant value 0.05 , so it is insignificant because greater than .005 .

Hence, from the above result discussion, Hypothesis $(\mathrm{H} 1, \mathrm{H} 2, \mathrm{H} 4$, H5) accepted and (H3, H6) rejected.

\section{Conclusion}

The present examination attempts to end up learned about Mastercard's idea and how behavior factors affect CCU. Behavior factors empower the holder of credit cards to make healthy use of credit cards. As per the investigation's consequences, the most powerful factor that positively affects credit card utilization is perceived usefulness and Perceive risk. Ultimately behavior factor is a need toward improving the better use of credit cards. Therefore, card clients will be well ready to make the sound card use. 
For further study, there is a need to consider another factor affecting credit card use like cost. The sample size should be increased, so its generalizability increases. Other cities in Pakistan are also included. And there is a need to add mediating or moderating Variable for better understanding.

\section{References}

Ajzen, I. (1991). The theory of planned behavior. Organizational Behavior and Human Decision Processes, 50(2), 179-211.

Barua, P. (2013). The moderating role of perceived behavioral control: The literature criticism and methodological considerations. International Journal of Business and Social Science, 4(10), 57.

Davis, F. D. (1989). Perceived Usefulness, Perceived Ease of Use, and User Acceptance of Information Technology . Management Information Systems Research Center, 320.

Eckhardt, A. (2009). The significant others of subjective norm-A scientometric study of subjective norm in IS top-journals over two decades. ECIS Proceedings (p. 417). ECIS. Retrieved from https://aisel.aisnet.org/ecis2009/417

Goyal, A. (2008). Managing perceived risk for credit card purchase through supplementary services. Journal of Financial Services Marketing, 12(4), 331-345.
Hardeep Chahal, G. K. (2014). Moderating role of perceived risk in credit card usage and experience link. Journal of Indian Business Research, 6(4), 286-308.

Jorgensen, A. M. (2013). College Students and Credit Card Use: The Role of Parents, Work Experience, Financial Knowledge, and Credit Card Attitudes. Journal of Family and Economic Issues, 34(4), 369-381.

Nyoman Trisna Herawati, I. M. (2018). Factors That Influence Financial Behavior Among Accounting Students in Bali. International Journal of Business Administration, 9(3), 30-38.

Shafinar Ismail, H. A. (2014). Determinants of Attitude towards Credit Card Usage. Jurnal Pengurusan, 41(2014), 145-154.

Sriyalatha, M. K. (2016). Determinants of Customers' Attitude towards Credit Card Usage: Lessons Learned from Academics in Sri Lanka. Case Studies in Business and M anagement, 3(2), 2333-3324.

Suhana Mohamed, N. S. (2016). a case study on Factors InfluencingCredit Card Usage. Journal of Applied Environmental and Biological Sciences Journal of Applied Environmental and Biological Sciences 6(1), 38-42.

Syed Faheem Hasan Bukhari, A. I. (2015). Inspecting the Dynamics Leading towards Credit Card usage . Global Journal of Management and Business Research, 15(9), 1-14. 